\title{
Relationship between Education Expenditure, Capital, Labor Force and Economic Growth in Malaysia
}

\author{
Norimah Rambeli @ Binti Ramli ${ }^{1}$, Emilda Hashim², \\ Dayang Affizah Awang Marikan ${ }^{3}$ \\ 1,2,3,4 Faculty of Management \& Economics, Sultan Idris Education University, Tanjung Malim, \\ Perak Darul Ridzuan 35900, Malaysia \\ (Correspondence: norimah@fpe.upsi.edu.my)
}

\begin{abstract}
Educational institutions play important role in producing highly educated communities. Investment in education an opportunities expansion to obtain higher education has become main economic development agenda in many countries, including Malaysia. Therefore, this study is conducted to examine the relationship between government expenditure and economic growth from 1970 to 2013. By using Cobb-Douglas Production Function in developing Multiple Regression Linear Model, the results show a significant and positive relationship between education expenditure and Malaysian economic growth. The findings further suggest that capital and labor force also influence economic growth in the long run.

Keywords: Education, Government Expenditure, Economic Growth
\end{abstract}

\section{INTRODUCTION}

Human capital plays a vital role in generating economic growth of a country especially at higher education level. Now, in line with the rapid technology advancement and increase competition has brought in major changes in the labor market. This situation has led to an increase in demand for employment. Currently, contemporary economy requires people with higher education to meet knowledgeable and skilled manpower.

Education and development are keys to improve the country's competitiveness. The education system must be able to meet the needs of commercial and industry, as well as producing innovative, productive and skilled workforce. Labor is also an important input in economic development and growth of a country. The formation of human capital through education and training will contribute to economic growth of a nation. According to Lucas (1993), education and training are agent of growth in producing human capital with knowledge and skills (quoted from Grillches, 1996).

The development of labor force is an ongoing process to improve the quality of human capital. This is in line with the government's agenda in the Malaysian Education Blueprint (2013-2025). Goals and approaches used by the Ministry of Education in producing national education system is based on five main aspirations characteristic of access, quality, equity, unity and efficiency. In drafting this plan, there are nine priority areas identified from the National Education Assessment Report which have been scrutinized. The first scope is related to uphold the dignity of the teaching profession, the second is to improve the quality of school 